

\title{
A Control Strategy Scheme for Fuel Cell-Vehicle Based on Frequency Separation
}

Hamza Alloui, Khoudir Marouani, Mohamed Becherif, Mohamed Nacereddine Sid, Mohamed El Hachemi Benbouzid

\section{- To cite this version:}

Hamza Alloui, Khoudir Marouani, Mohamed Becherif, Mohamed Nacereddine Sid, Mohamed El Hachemi Benbouzid. A Control Strategy Scheme for Fuel Cell-Vehicle Based on Frequency Separation. IEEE 1st International Conference on Green Energy, Mar 2014, Sfax, Tunisia. 10.1109/ICGE.2014.6835417 . hal-03221959

\section{HAL Id: hal-03221959 \\ https://hal.science/hal-03221959}

Submitted on 10 May 2021

HAL is a multi-disciplinary open access archive for the deposit and dissemination of scientific research documents, whether they are published or not. The documents may come from teaching and research institutions in France or abroad, or from public or private research centers.
L'archive ouverte pluridisciplinaire HAL, est destinée au dépôt et à la diffusion de documents scientifiques de niveau recherche, publiés ou non, émanant des établissements d'enseignement et de recherche français ou étrangers, des laboratoires publics ou privés. 


\section{A Control Strategy Scheme for Fuel Cell-Vehicle Based on Frequency Separation}

\author{
Hamza Alloui \\ Laboratoire Commande des \\ Machines \\ École Militaire Polytechnique \\ Algiers, Algeria \\ alloui_hamza@yahoo.fr
}

\author{
Khoudir Marouani \\ Laboratoire Commande des \\ Machines \\ École Militaire Polytechnique \\ Algiers, Algeria \\ marouani_khoudir@yahoo.fr
}

\author{
Mohamed Becherif \\ UTBM, FCLAb FR \\ CNRS 3539, Femto-ST \\ UMR CNRS 6174, 90010 \\ Belfort, France \\ mohamed.becherif@utbm.fr
}

\author{
Mohamed Nacer Sid \\ Laboratoire Commande des \\ Machines \\ École Militaire Polytechnique \\ Algiers, Algeria \\ Sidmednacer@hotmail.fr
}

\author{
M.E.H Benbouzid \\ Université de Brest, \\ EA 4325 LBMS \\ Rue de Kergoat, CS 93837, 29238 \\ Brest Cedex 03, France \\ Mohamed.Benbouzid@univ-brest.fr
}

\begin{abstract}
This paper presents a control strategy scheme based on frequency-separation for Fuel cell-Battery Hybrid Electric Vehicle (HEV), using a Fuel cell (FC) as a main energy source, and a battery as an auxiliary power source. First, an analysis of hybrid architecture using an FC and batteries for automotive applications is presented. Next, the model and the control strategy are described.

In this strategy a frequency splitter is used for routing the low frequency content of power demand into the FC and its high frequencies into the battery, taking profit from the battery as a peak power unit.
\end{abstract}

Simulation and experimental results validate the performance of this strategy.

Keywords - Fuel cell, hybrid source, battery, DC-DC Boost converter, Buck-boost converter, Frequency separation Energy Management.

\section{INTRODUCTION}

The world faces a serious challenge in energy demand and supply. People around the world consume approximately 85 million barrels of oil every day but there are only 1300 billion barrels of proven reserves of oil. At the current rate of consumption, the world will run out of oil in 2050. New discoveries of oil reserves are at a slower pace than the increase in demand. Among the oil consumed around the world, $60 \%$ is used for transportation [1].

Gasoline and diesel fuel-powered vehicles are among the major contributors to $\mathrm{CO}_{2}$ emissions. In addition, there are other emissions from conventional fossil fuel-powered vehicles, including carbon monoxide (CO) and nitrogen oxides ( $\mathrm{NO}$ and $\mathrm{NO}_{2}$, or $\mathrm{NO}_{\mathrm{x}}$ ) from burning gasoline; hydrocarbons or volatile organic compounds (VOCs) from evaporated, unburned fuel; and sulfur oxide and particulate matter (soot) from burning diesel fuel. These emissions cause air pollution and ultimately affect human and animal health [1].

It is why the society needs sustainability, but the current model is far from it. Cutting fossil fuel usage and reducing carbon emissions are part of the collective effort to retain human uses of natural resources within sustainable limits.

Therefore, future personal transportation should provide enhanced freedom, sustainable mobility, and sustainable economic growth and prosperity for society. In order to achieve these, vehicles driven by electricity from clean, secure, and smart energy are essential, but electrically driven vehicles have many advantages and challenges. Hybrid vehicles and fuel cells can be one of the solutions.

Fuel cell vehicles (FCVs) use FCs to generate electricity from hydrogen. The electricity is either used to drive the vehicle or stored in an energy storage device, such as battery pack. Since FCs generates electricity from chemical reaction, they do not burn fuel and therefore do not produce pollutants. The byproduct of a hydrogen FC is water and heat. FCVs provide quiet operation and more comfort with zero emissions. These vehicles are efficient, reliable, optimum, and long lasting at reasonable cost. They have greater efficiency compared to heat engines; FCVs could be a long-term solution [2].

\section{FUEL CELLS}

The developments leading to an operational FC can be traced back to the early 1800's with Sir William Grove recognized as the discoverer in1839. A FC is an energy conversion device that converts the chemical energy of a fuel directly into electricity. Energy is released whenever a fuel (hydrogen) reacts chemically with the oxygen of air. The reaction occurs electrochemically and the energy is released as a combination of electrical energy (low-voltage DC) and heat [3].

FC consists of an electrolyte sandwiched between two electrodes. The electrolyte has a special property that allows positive ions (protons) to pass through while blocking electrons. Hydrogen gas passes over one electrode, called an anode, and with the help of a catalyst, separates into electrons and hydrogen protons, as shown in Fig.1.

The chemical reaction describing this process is [4] 


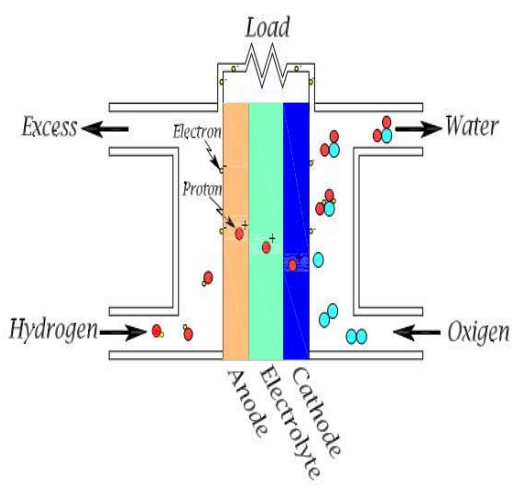

Fig. 1.Fuel cell reaction [4]

$$
2 \mathrm{H}_{2} \Rightarrow 4 \mathrm{H}^{+}+4 e^{-}
$$

The protons pass through the electrolyte towards the cathode, and the electrons close the circuit through the electric load, performing electric work. In the cathode, the protons and electrons combined with oxygen produce water, this reaction is described by:

$$
\mathrm{O}_{2}+4 \mathrm{H}^{+}+4 e^{-} \Rightarrow 2 \mathrm{H}_{2} \mathrm{O}
$$

The overall reaction that takes place in the fuel cell is:

$$
2 \mathrm{H}_{2}+\mathrm{O}_{2} \Rightarrow 2 \mathrm{H}_{2} \mathrm{O}
$$

Hydrogen oxidation and oxygen reductionare separated by the membrane $(20-200 \mu \mathrm{m})$ which carries protons from the anode to the cathode and is impermeable to electrons (Fig.2). This protons flow drags water molecules as gradient of humidity, leads to water diffusion according to the local humidity of the membrane. Water molecules can then go in both directions inside the membrane, according to the side where the gases are humidified and the current density, which is directly related to the protons flow through the membrane and the water produced on the cathode side. Electrons that appear on the anode side cannot cross the membrane, so, they pass through the external circuit before reaching the cathode [5].

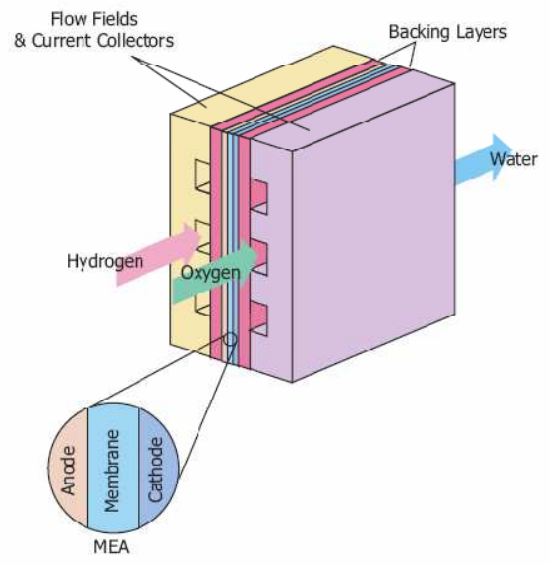

Fig. 2 Fuel cell structure [6]

As the gases are supplied in excess to ensure a good cell operating, the non-consumed gases leave the FC carrying with them the produced water [5].

Generally, a water circuit is used to impose the FC operating temperature (around $60-80{ }^{\circ} \mathrm{C}$ ). At start up, the FC is warmed and later cooled, as at the rated current nearly, the same amount of energy is produced under heat form than under electrical form [5].

Types of FCs differ principally according the type of electrolyte they utilize [4]. The type of electrolyte, which is a substance that conducts ions, determines the operating temperature, which varies widely between types. Proton Exchange Membrane Fuel Cells (PEMFCs) are presently the most promising type of FC for automotive use and have been used in the majority of prototypes built to date[5].

\section{BATTERIES IN FCV}

At the present time and in the foreseeable future, batteries have been agreed to be the major energy source for EVs [7]. In FCVs, batteries are used as secondary source; these batteries have high power density. The internal resistance is the major factor for the limited discharging and charging current capability. The internal equivalent series resistance has different values under charging and discharging operating conditions. The charging and discharging efficiency are nonlinear functions of current and state of charge (SOC). The battery can be modeled as an equivalent circuit such as a voltage source and an internal resistor.

There are many technologies of batteries used in HEVs:

\section{A. Lead-Acid Batteries}

The lead-acid battery presents several advantages for HEV applications. They are available in production volumes today, yielding a comparatively low-cost power source. In addition, lead-acid battery technology is a mature technique due to its wide use over the past 50 years [8]. The battery energy and power density are low due to the weight of lead collectors.

\section{B. Nickel-Metal Hydride (NiMH) Batteries}

The energy density of the NiMH battery is twice that of the lead-acid battery. The NiMH battery is safe to operate at high voltage and has distinct advantages, such as storing volumetric energy and power, long cycle life, wide operation temperature ranges, and a resistance to cover charge and discharge. On the other hand, if repeatedly discharged at high load currents, the memory effect in $\mathrm{NiMH}$ battery systems reduces the usable power for the $\mathrm{HEV}$, which reduces the usable SOC of the battery to a value smaller than $100 \%$ [9]. 


\section{Lithium-Ion Batteries}

The lithium-ion battery has been proven to have excellent performance in portable electronics and medical devices. The lithium-ion battery has high energy and power density, with good high temperature performance, moreover it is recyclable. The promising aspects of the Li-ion batteries include low memory effect, high specific power of 300 $\mathrm{W} / \mathrm{kg}$, high specific energy of $100 \mathrm{Wh} / \mathrm{kg}$, and long battery life of more than 1000 cycles [9]. These excellent characteristics give the lithium-ion battery a high possibility of replacing $\mathrm{NiMH}$ as next-generation batteries for vehicles. Table I demonstrates the characteristics of commercially available lead-acid, NiMH, and Li-ion batteries for vehicles [10].

\section{Nickel-Zinc (Ni-Zn) Batteries}

Nickel-Zinc batteries have high energy and power density, low-cost materials, and deep cycle capability and are environmentally friendly. However, they suffer from poor life cycles due to the fast growth of dendrites, which prevents the development of $\mathrm{Ni}-\mathrm{Zn}$ batteries in vehicular applications [9].

\section{E. Nickel-Cadmium (Ni-Cd) Batteries}

Nickel-cadmium batteries have a long lifetime and can be fully discharged without damage. The specific energy of $\mathrm{Ni}-\mathrm{Cd}$ batteries is around $55 \mathrm{Wh} / \mathrm{kg}$, but it has low power density.

\section{MODELLING OF HYBRID DC SOURCES}

\section{A. Structure of the hybrid source}

As shown in Fig. 3, the studied system comprises a DC link supplied by a FC and a non-reversible DC-DC Boost converter, which maintains the DC voltage $V_{D C}$ to its reference value $\overline{V_{D C}}$ and a battery storage device, which is connected to the DC link through a current reversible DCDC converter. The function of FC is to supply the mean power to the load, whereas the storage device is used as a power source: it supplies peak loads required during acceleration and braking [5].



Fuel Cell

Fig. 3 Hybrid sources structure

\section{B. Dynamic modeling}

The hybrid structure is given by Fig.4. It is composed of a FC as a main source associated to a DC-DC Boost converter, a battery source connected to a current bidirectional DC-DC current converter, a DC Bus and a RL load. [11].

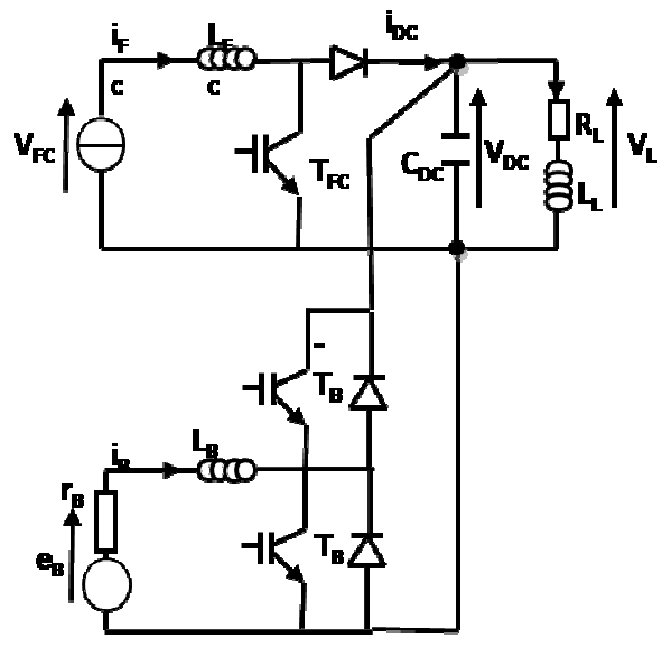

Fig. 4 Hybrid sources electrical model [11]

Where $\mathrm{V}_{\mathrm{FC}}, \mathrm{i}_{\mathrm{FC}}, \mathrm{L}_{\mathrm{FC}}$ and $\mathrm{T}_{\mathrm{FC}}$ are respectively the $\mathrm{FC}$ voltage, current, inductance and transistor, and $\mathrm{e}_{\mathrm{B}}, \mathrm{i}_{\mathrm{B}}, \mathrm{r}_{\mathrm{B}}$, $L_{B}$ and $T_{B}$ are successively the battery voltage, current, resistance, inductance and transistor, and $\mathrm{V}_{\mathrm{DC}}, \mathrm{i}_{\mathrm{DC}}$ and $\mathrm{C}_{\mathrm{DC}}$ are the DC bus voltage, DC bus current and DC bus capacitor and $\mathrm{R}_{\mathrm{L}}, \mathrm{L}_{\mathrm{L}}$ are the load resistance and inductance.

\section{B.1 PEMFC model (static model)}

The characteristic of the voltage versus current of the FC is presented in Fig. 5. The obtained curve is composed of three main regions corresponding to the electrochemical activation phenomena (region 1), a linear part (region 2) where the voltage drop is due to electronic and ionic internal resistances, and the last region where the diffusion kinetics of gases through the electrodes becomes the limiting factor (region 3). This last zone is characterized by a brutal voltage fall.

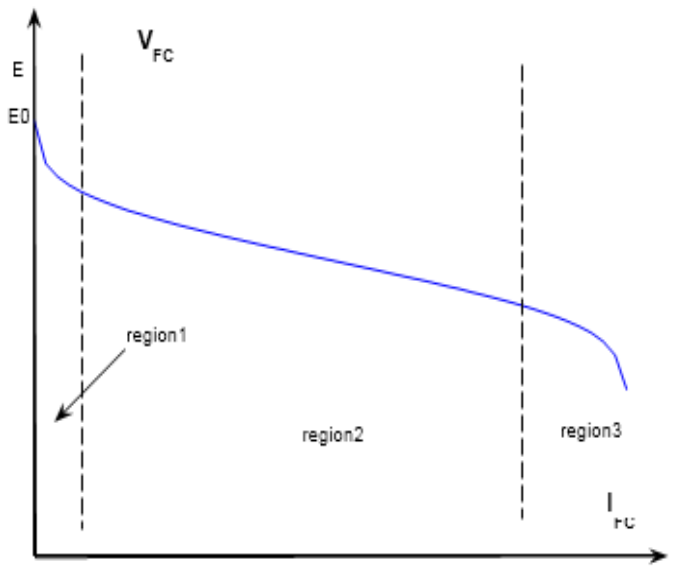

Fig. 5Static FC characteristic [5] 


$$
V_{F C}=E-A * \log \left(\frac{i_{F C}+i_{n}}{i_{0}}\right)-R_{m}\left(i_{F C}+i_{n}\right)+B \log \left(1-\frac{i_{F C}+i_{n}}{i_{L i m}}\right)
$$

Hence $V_{F C}=f\left(i_{F C}\right)$, where $\mathrm{E}$ is the reversible no loss voltage of the $\mathrm{FC}, \mathrm{E}_{0}$ is the measured open circuit voltage, $\mathrm{i}_{\mathrm{FC}}$ is the delivered current, $\mathrm{i}_{\mathrm{O}}$ is the exchange current, $\mathrm{A}$ is the slope of the Tafel line, $i_{\text {Lim }}$ is the limiting current, $B$ is the mass transfer constant, $\mathrm{i}_{\mathrm{n}}$ is the internal current and $\mathrm{R}_{\mathrm{m}}$ is the membrane and contact resistances [5].

\section{B.2 PEMFC and FC Boost converter model}

$$
\frac{d i_{F C}}{d t}=\frac{1}{L_{F C}}\left[V_{F C}-\left(1-\mu_{F C}\right) V_{D C}\right]
$$

Where if $\mu_{F C}=1 \Leftrightarrow T_{F C}$ is closed

\section{B.3 DC bus model}

$$
\frac{d V_{D C}}{d t}=\frac{1}{C_{D C}}\left[\left(1-\mu_{F C}\right) i_{F C}-i_{L}-\left(1-\mu_{B}\right) i_{B}\right]
$$

Where if $\mu_{B}=1 \Leftrightarrow T_{B}$ is closed and $\overline{T_{B}}=0$

B.4 Battery + Battery DC-DC converter model

$$
\begin{aligned}
& V_{B}=e_{B}-r_{B} i_{B} \\
& \frac{d i_{B}}{d t}=\frac{1}{L_{B}}\left[V_{B}-\left(1-\mu_{B}\right) V_{D C}\right]
\end{aligned}
$$

B.5 R,L load model

$$
\frac{d i_{L}}{d t}=\frac{1}{L_{L}}\left[V_{L}-R_{L} i_{L}\right]
$$

$$
V_{L}=V_{D C}
$$

The overall model of the hybrid system can be written in a state space model by choosing the following state space vector:

$$
x=\left[x_{1}, x_{2}, x_{3}, x_{4}\right]^{T}=\left[i_{F C}, V_{D C}, i_{B}, i_{L}\right]^{T}
$$

The control vector is

$$
\mu=\left[\mu_{1}, \mu_{2}\right]^{T}=\left[\left(1-u_{F C}\right),\left(1-u_{B}\right)\right]^{T}
$$

Or

$$
u=\left[u_{F C}, u_{B}\right]^{T}
$$

The $4^{\text {th }}$ order overall state space model is then:

$$
\begin{aligned}
& \dot{x_{1}}=\frac{1}{L_{F C}}\left[-\mu_{1} x_{2}+V_{F C}\right] \\
& \dot{x_{2}}=\frac{1}{C_{D C}}\left[\mu_{1} x_{1}+\mu_{2} x_{3}-x_{4}\right] \\
& \dot{x_{3}}=\frac{1}{L_{B}}\left[-\mu_{2} x_{2}+e_{B}-r_{B} x_{3}\right] \\
& \dot{x_{4}}=\frac{1}{L_{L}}\left[-R_{L} x_{4}+x_{2}\right] \\
& y=x_{2}
\end{aligned}
$$

With $V_{F C}=V_{F C}\left(x_{1}\right)$ given by (5). $\mathrm{V}_{\mathrm{FC}}$ is considered as a measured disturbance, and from physical consideration, it comes that $V_{F C} \in\left[0, V_{d}\right]_{\text {where }} V_{d}$ is the desired DC bus voltage.

\section{SIMULATION RESULTS OF THE CONTROL STRATEGY}

An implicit purpose of the proposed structure (Fig.4) is to use the battery as a power source supplying the transient peak power. Simulation (Fig.6) shows an energy management based on frequency separation [12], [13], [14], where a PI regulator is used to regulate the DC bus voltage $\left(\mathrm{V}_{\mathrm{DC}}\right.$ ) (Fig.8) and to give the DC bus current reference $\left(i_{\text {DCref }}\right)$, this reference is filtered with low-pass filter to obtain the FC reference current ( $i_{\text {FCref }}$ ) (Fig.9), the cut-off frequency of the filter is chosen so that the $\mathrm{FC}$ current is very smooth $(\tau=0.8 s)$. A PI controller of the FC current gives the control voltage of the boost converter; the control pulses sent to the IGBT of the boost chopper are obtained by applying the PWM on this control voltage. The battery reference current $\left(i_{B}\right)$ is calculated by the difference between the DC bus reference current and the FC reference current (Fig.9) [11], [15], [16].

A step of load current was applied at $0.5 \mathrm{~s}$ (Fig.7) in order to evaluate the sources responses to peaks of current.

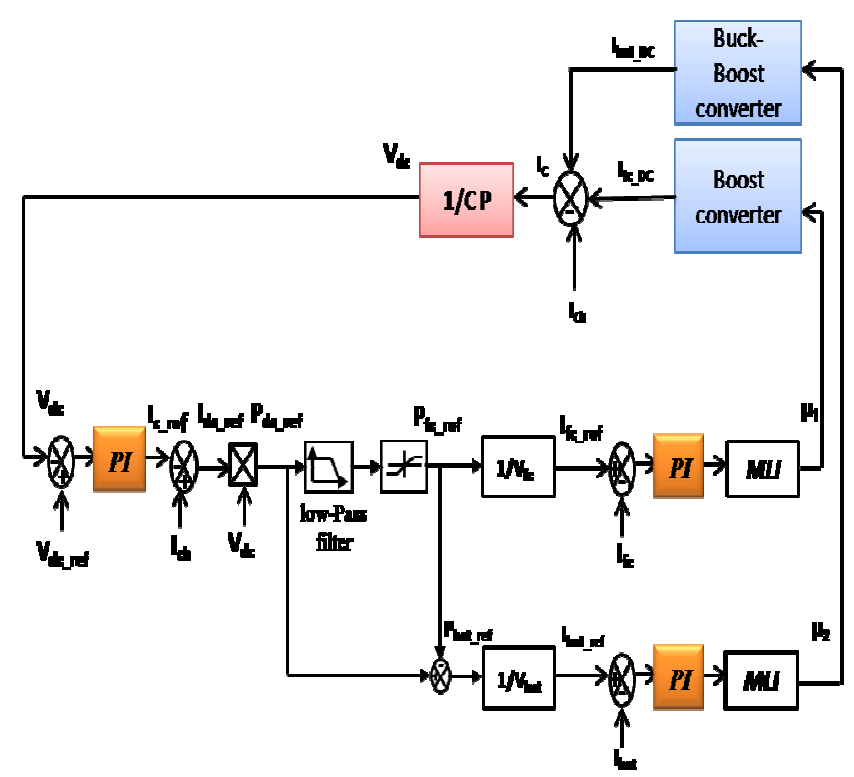

Fig. 6 Global control strategy of energy management based on frequency separation 


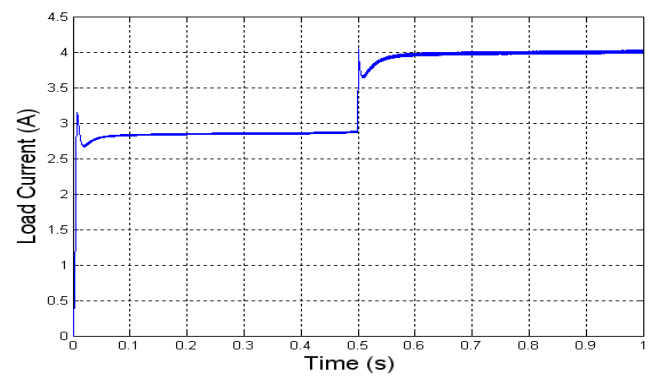

Fig. 7 Load current



Fig. 8DC Bus voltage with reference value 100V

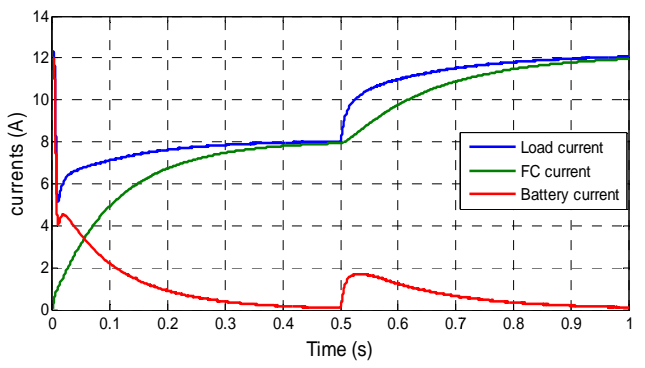

Fig. 9 Reference values of load current, FC and battery currents

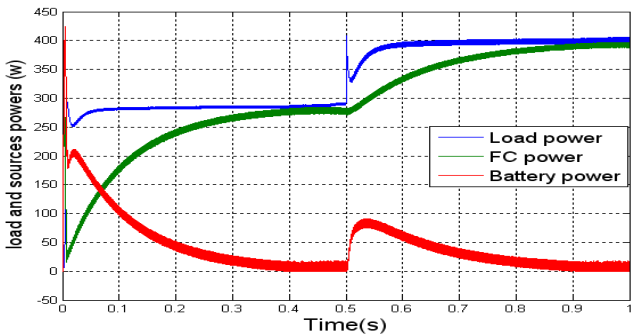

Fig. 10Load and sources powers

Figure 8 shows the response of the $\mathrm{DC}$ bus voltage $\mathrm{V}_{\mathrm{DC}}$ to load current change (at $\mathrm{t}=0.5 \mathrm{~s}$ ), The DC Bus voltage tracks well the reference $\mathrm{V}_{\mathrm{DCref}}=100 \mathrm{~V}$.

Figure 9 shows the FC current reference $i_{\mathrm{FCref}}$, a smooth behavior of the FC current is observed regarding the change in the load current, this is because the battery supplies the transient current. Figure 9 shows also the battery current reference $i_{\text {Bref }}$ response in presence of a load current change. The battery supplies power to the load in the start-up and transients operations. Figure10 shows the load power with sources powers.

\section{EXPERIMENTAL RESULTS}

The experimental test bench consists of: a power generator replaces the Fuel cell, two batteries Lead-Acid $12 \mathrm{~V} / 12 \mathrm{Ah}$, Boost converter, buck-boost converter, variable resistor simulating the toad, sensors card and stabilized power supply.

The energy management based on frequencies separation algorithm has been implemented on eZdsp-F2812 DSP controller.

In Fig. 11, load current step variation has been applied, in order to evaluate the performance of the control strategy. The FC current is smoothed, while high-frequency components are present in the battery current (Fig. 11).

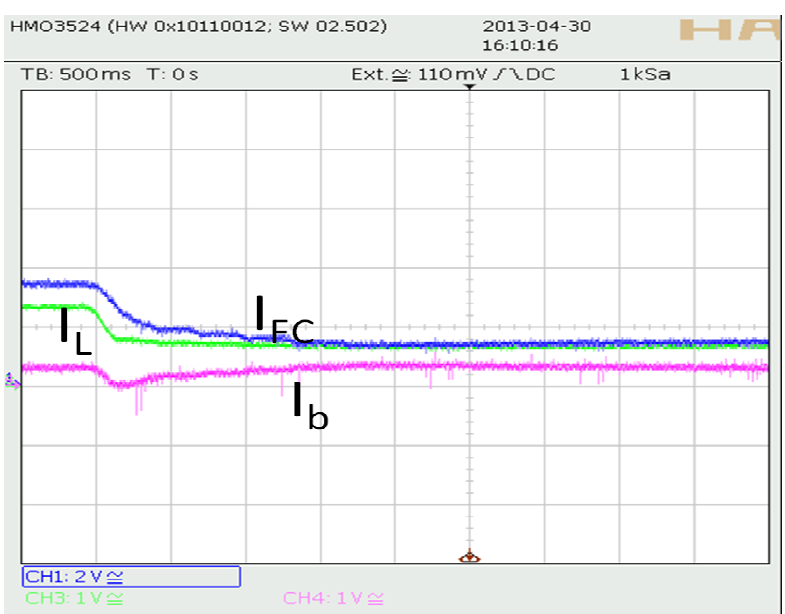

Fig.11. The performance of the control strategy under load current variations (1s/div, 2A/div).

\section{CONCLUSION}

This paper presents a frequency-separation-based energy management strategy for the case of power sources hybridization for an electric vehicle. While using a FC as main power source, the electric vehicle is also equipped with battery able to support fast and large variations of power demand.

A dynamic modeling of a hybrid sources system is presented (with a static model of the FC).

A simple control method of power sources based on a physical constraint of FC, which is the low current response time, is presented in this paper, in order to increase FC life time. For that, the DC bus reference current is filtered by a low-pass filter to obtain the FC reference current.

Encouraging simulation results have been obtained and discussed exhibiting the robustness of the proposed control towards load currentsudden changes, and to validate the present work, experimentations have been carried out validating the simulation results.

\section{REFERENCES}

[1] C.Mi, M. AbulMasrur, David Wenzhong Gao, "Hybrid electric vehicles: Principles and applications with practical perspectives", John Wiley \& Sons, Ltd, Edition first published 2011. Page(s): 1 - 8

[2] H.Moghbelli, A.Halvaei and N.R.Langari, "New Generation of PassengerVehicles: FCV or HEV?" Industrial Technology, ICIT 2006.Page(s): 452 - 459 
[3] M.Becherif, M.Y.Ayad and A.Miraoui"Modeling and Passivity-Based Control of Hybrid Sources: Fuel Cell and Supercapacitors",Industry Applications Conference, 2006. $41^{\text {st }}$ IAS Annual Meeting. Page(s): $1134-1139$

[4] A. SANCHEZ,"Energy Management in Electric Systems Fed by Fuel Cell Stacks ", PhD thesis, Laboratoire Des Signaux Et SystemesUniversite Paris-Sud XI 2011.

[5] M.Becherif, "Passivity-Based Control Of Hybrid Sources: Fuel Cell And Battery", $11^{\text {th }}$ IFAC Symposium on control in Transportation (CTS'06), Netherland, 2006.

[6] J.T.Pukrushpan,"Modeling and control of Fuel Cell systems and fuel processors ", PhD thesis, Mechanical Engineering, University of Michigan, 2003.

[7] C.C. Chan, "The State of the Art of Electric and Hybrid Vehicles",ProcIEEE, Vol. 90, Nº 2.febr2002.Page:266

[8]O. Caumont, P. Le Moigne, C. Rombaut, X. Muneret, and P. Lenain,"Energy gauge for lead-acid batteries in electric vehicles", IEEE Trans. Energy Convers., vol. 15, no. 3, pp. 354-360, Sep. 2000.

[9]A. Khalighand L. Zhihao"Battery, Ultracapacitor, Fuel Cell, and Hybrid Energy Storage Systems for Electric, Hybrid Electric, Fuel Cell, and Plug-In Hybrid Electric Vehicles: State of the Art",IEEE Trans on Vehicular Technology, Vol. 59, No. 6, July 2010, pp. 2806-2814.

[10]A. Cooper and P. Moseley,"Progress in the development of lead-acid batteries for hybrid electric vehicles",Proc. IEEE Vehicle Power Propulsion Conf., Sep. 2006, pp. 1-6.

[11]H. Alloui, M. Becherif, K. Marouani, "Modelling and Frequency Separation Energy Management of Fuel CellBattery Hybrid Sources System for Hybrid Electric Vehicle", 21 st Mediterranean Conference on Control \& Automation (MED), June 2013.pp. 1-6.

[12]Florescu.A, Bacha.S. Munteanu, I.Bratcu, A.I."Frequencyseparation-based energy management control strategy of power flows within electric vehicles using ultracapacitors",IECON 2012 - 38th Annual Conference on IEEE Industrial Electronics Society.

[13]Curti, J.M.A., Huang, X.,Minaki, R.; Hori, Y."A simplified power management strategy for a supercapacitor/battery Hybrid Energy Storage System using the Half-Controlled Converter",IECON 2012 - 38th Annual Conference on IEEE Industrial Electronics Society.

[14]Blanes, J.M., Gutierrez, R.; Garrigos, A.; Lizan, J.L.; Martinez, J."Electric Vehicle Battery Life Extension Using Ultracapacitors and a FPGA Controlled Interleaved BuckBoost Converter ",IEEE Trans. power. Electron.,Early Access Articles. 2013.

[15]Florescu.A, Bacha.S.,Munteanu, I.Bratcu, A.I.Rumeau, A."Results concerning ultracapacitor-based energy management strategy within electric vehicles"16th International Conference on System Theory, Control and Computing (ICSTCC), 2012

[16] T.Azib, O.Bethoux, Member, IEEE, G.Remy, Member, IEEE, and C. Marchand, Member, IEEE "Saturation Management of a Controlled Fuel-Cell/Ultracapacitor Hybrid Vehicle"IEEE Trans on Vehicular Technology, Vol. 60, NO. 9, Nov 2011 